Article

\title{
SWOT Analysis of the Application of International Standard ISO 14001 in the Chinese Context. A Case Study of Guangdong Province
}

\author{
Marco Pesce $\left.{ }^{1} \mathbb{(}\right)$, Chenyi Shi ${ }^{2}$, Andrea Critto ${ }^{1, * \mathbb{C}}$, Xiaohui Wang ${ }^{3}$ and Antonio Marcomini ${ }^{1}$ \\ 1 Department of Environmental Sciences, Informatics and Statistics, University Ca' Foscari of Venice, \\ 30123 Venezia VE, Italy; marco.pesce@unive.it (M.P.); marcom@unive.it (A.M.) \\ 2 School of Greography and Planning, Sun Yat-Sen University, Guangzhou 510275, China; \\ shicheny@mail2.sysu.edu.cn \\ 3 EHS Center, Lingnan College, Sun Yat-Sen University, Guangzhou 510275, China; wangxh@mail.sysu.edu.cn \\ * Correspondence: critto@unive.it; Tel.: +39-041-234-8975
}

Received: 6 August 2018; Accepted: 4 September 2018; Published: 6 September 2018

\begin{abstract}
Industry has long been one of the most important drivers of Chinese economic growth. In order to improve the environmental footprint of industrial areas, Chinese authorities have established mechanisms of environmental control in the internal management processes of companies. In this regard, the international standard ISO 14001 for environmental management systems is the management tool that has had widest adoption among Chinese companies since its creation in 1996. The main purposes of the paper are to investigate the available international and national statistics on the adoptionof ISO 14001 in China, and present opinions on ISO 14001 of the 72 representatives of small and medium enterprises and multinational companies of Guangdong province that participated to the workshop "New tools and standards to advance and measure corporate sustainability", held in Guangzhou on 26 January 2018. The analysis of strengths, weaknesses, opportunities and threats (SWOT) was adopted as the research method to collect opinions on the ISO 14001 standard. Participants were asked to discuss strengths, weaknesses, threats and opportunities considering four business aspects: sustainability, internal processes, stakeholder engagement, and resource management. Our findings indicate that companies fully embraced ISO 14001 and recognized the necessity of a standardized approach to identify environmental aspects. On the other hand, they also expressed concern about aspects such as the certification cost, the focus on certification itself and not on the improvement of environmental performance, and the lack of integration with sustainability tools such as life cycle assessment (LCA) and other sustainability paradigms such as circular economy and corporate social responsibility (CSR).
\end{abstract}

Keywords: ISO 14001; ISO 14001:2015; environmental management systems; environmental management; corporate sustainability

\section{Introduction}

The past few decades have witnessed the rapid development of China, which has developed as the second economy in the world. However, the long-term economy-oriented development characterized as "high input, high consumption and high emissions" was achieved at the expense of the environment [1]. With the ongoing global climate change, shortage of national resources and environmental deterioration, China's moves on environmental protection have drawn the world's attention.

With the situation changed in terms of environmental degradation, the improved diplomatic relationship between China and foreign countries as well as the United Nation's conference on 
the Human Environment held in 1972, China started the journey to environmental protection [2], which can be described through four stages of environmental policies. In the first stage (1970s), China legally defined the concept of environmental protection, represented by the first National Conference on Environmental Protection in 1973, during which the first legal document "Regulations on Protecting and Improving the Environment" was adopted. According to this document, the first official organization in environmental protection-the Environmental Protection Leading Group of the State Council of the People's Republic of China-was established in 1974 and the first Environmental Protection Law (Trial) was enacted in 1979 [2].

In the second stage (1980s), the Second National Conference on Environmental Protection was held in 1983, when environmental protection was announced as one of the basic state policies in China [3] and a systematic principle of environmental protection was proposed. In 1989, the Third National Conference on Environmental Protection took place and focused on the enhancement of new environmental management measures. Moreover, the Committee of the State Council on Environmental Protection was established in 1984, and so was the National Environmental Protection Agency (NEPA) under the Ministry of Construction, which was upgraded to the State Environmental Protection Administration (SEPA) in 1998 and replaced by the Ministry of Environmental Protection in 2008 [3].

The third stage (1990s) witnessed a major transition in environmental strategy, when China set down the sustainable development strategy as one of the two basic national strategies, and issued China's 21st Century Agenda, which stressed the necessity of cleaner production in industry [4]. The second National Conference on the Prevention and Control of Industrial Pollution proposed "three shifts": the shift from end-of-pipe treatment to the whole-process control, shift from concentration control to both concentration control and amount control, and the shift from scattered treatment to a combination of scattered and centralized treatments [3]. From then on, cleaner production was incorporated into environmental management at different levels as well as into related laws. Since the Fourth National Conference on Environmental Protection in 1996, "Total Emissions Control" and the "Green Project" have been implemented as two major measures. Except for the pollution control, China began to focus on ecological conservation in the late 1990s [5].

The 21st century started the fourth stage of China's environmental policy. At this stage China began to implement environmental policy in a more comprehensive way [6]. For one thing, China has shifted from solely administrative measures to an integrated approach of legal, economic, technological administrative measures, with more laws and policies adopted. For another, the policies emphasized the coordination and "win-win" strategies between economic development and environmental protection instead of any single aspect. Along with the concept of the "circular economy" and "resource-saving society", the central government summarized the environmental policy as "one core, two principles and three routes". Specifically, the Scientific Outlook on Development was regarded as the core concept; the two principles referred to "energy efficiency and pollutant discharge reduction" and "building a resource-saving and environmentally friendly society"; the three routes meant cleaner production, a circular economy, and the proper adjustment of environmental protection and economic development [6].

As stated above, China's environmental policy has undertaken great changes in the past few decades, presenting four features: the increasing importance of becoming one of the basic state policies; the change from a single administrative measure to an integrated approach of legal, economic, technological administrative measure; the emphasis on the coordination of environmental protection and economic development; and the shift from end-of-pipe treatment to the whole process control of industry.

This policy evolution process has been operatively translated into the industrial sector. In particular, in order to mitigate the environmental impacts caused by increasing industrial development [7], Chinese manufacturers have committed to the adoption of environmental management approaches that encourage the implementation of more environmentally sustainable 
practices, compliance with environmental regulations, and a better use of natural resources $[8,9]$. To incorporate environmental management principles into internal management practices of businesses, Chinese manufacturers have implemented a series of approaches based on environmental management systems (EMSs) [10,11], cleaner production [12,13], a circular economy [14,15], eco-efficiency and eco-design [16,17], and green supply chain management [18,19]. In particular, the last two decades have witnessed a strong commitment of Chinese manufacturers to the implementation of EMSs under the international standard ISO 14001 [20]. The ISO 14001 certification is an internationally recognized commitment of an organization towards the implementation of a management system to continuously improve its environmental performance [21]. Previous studies on ISO 14001 in China mainly focused on the geographical and sectoral extent and distribution of the certification [22,23], reasons behind adoption [24,25], and effects on firms' performance [11]. However, studies assessing the perceptions that firms have of ISO 14001 not only in relation to environmental performance, but also on other perspectives such as sustainability (intended as economic, environmental, and social sustainability), operational, and governance, can be strategic and offer great opportunities for further investigation. Moreover, there is great need to identify and understand the benefits and problems that the application of ISO 14001 can bring to companies in those countries like China, which are currently experiencing rapid expansion of certification [23]. Finally, in a time where other important sustainability themes such as corporate social responsibility (CSR) [26,27] and circular economy [28-30] are becoming increasingly relevant, it is crucial to begin to understand the position of ISO 14001 in the new, evolving landscape of corporate sustainability.

Against this background, what follows is a qualitative assessment of the opinions on the standard ISO 14001 of a cluster of small and medium companies (SMEs) and multinational companies (MNCs) based in Guangdong province of China through the analysis of strengths, weaknesses, opportunities and threats (SWOT) method. The analysis identifies strengths, weaknesses, opportunities and threats of ISO 14001 certification for four different aspects: sustainability, internal processes and operations, stakeholder engagement, and resource management. The paper proceeds as follows: necessary background on EMSs and specifically on ISO 14001 is presented in Section 2. Recent literature on ISO 14001 in China is presented in Section 3. The methodology and results are presented and discussed in Section 4. Conclusions are presented in Section 5.

\section{Environmental Management Systems (EMS)}

An EMS is a structured framework for managing the environmental aspects and impacts of an organization. It can be developed internally by a company or follow the guidelines of voluntary standards. These standards are global regulatory mechanisms that address topics such as environment, quality, health and safety in organizations and their supply chains [31,32]. Different standards for EMSs exist, including ISO 14001:2015 [33], EMAS [34], and BS8555 [35].

EMSs first appeared in North America in the 1970s and are now widely used by organizations all over the world [36]. McGuire [21] states that voluntary standards for EMSs are cost-effective tools developed to overcome the deficiencies of traditional regulatory instruments, such as command-and-control regulations. The voluntary aspect of these standards is very important, as they do not replace environmental regulations but only provide guidelines in addressing environmental and business issues [37]. Companies decide to voluntarily over-comply with environmental regulations mainly in order to gain competitive advantage [38], enhance or restore their reputation [39] and to strategically anticipate the tightening of future environmental regulations [40]. Regardless of the reason behind certification, these standards provide the guidelines to potentially improve both the environmental and business performance of companies.

An EMS cannot be considered as an independent management tool, but as a sub-set of the overall management system (MS) of a company, which is usually completed by a quality management system (QMS) such as ISO 9001:2015 [41], and an occupational health and safety management system (OHSMS), such as ISO 45001:2018 [42]. Organizations are not limited to these three aspects and 
can decide to implement other standardized MSs specific for their industrial sector. For example, a food-processing firm may decide to implement a food safety management system (FSMS) such as ISO 22000:2018 [43]. Each of these standards require organizations to meet the requirements and produce a significant amount of documentation in the form of written procedures, checking, control forms and other paperwork [44]. As a result, it has been proved that it is difficult to handle separately these MSs and successfully ensure their alignment with the organization's strategy [45]. Hence, integrated management systems (IMS) have become a widely adopted solution for overcoming the problems resulting from multiple MSs. There is evidence of the adoption of IMSs in organizations operating in different sectors with a wide range of dimensions and in the majority of countries [46]. A study conducted by Zeng and colleagues to understand the IMS implementation in enterprises in China identified a series of major problems in operating parallel MSs, such as the increasing complexity of internal management, employee hostility and increasing management costs. The study also observed that Chinese firms follow a specific implementation approach: all the firms involved in the study established a QMS first and subsequently an EMS. This is related to the way international standards for MSs were introduced to China. Karapetrovic and Willborn [47] pointed out that this approach is the easiest way to implement an IMS.

ISO 14001, developed by the International Organization for Standardization (ISO) in 1996, is currently the most widely recognized and studied EMS standard in circulation [48,49]. The standard relies on the assumption that an improved environmental performance can be obtained by the systematic identification of relevant environmental aspects and their management through pollution prevention, improved environmental performance and compliance with applicable laws [50]. In the last decade, the number of firms that have obtained ISO 14001 certification has increased threefold, reaching the number of 346,189 certificates in 175 countries by the end of 2016 [51]. The purpose of this standard is to provide organizations of any type with a systematic framework which leads to [33]: prevention and mitigation of adverse environmental impacts; mitigation of potential adverse effect of environmental conditions on the organization; fulfillment of local legal obligations; enhanced environmental, financial and operational performance; and sound environmental communication to relevant stakeholders. It does so by establishing measurable environmental targets, procedures to reach targets, roles and responsibilities to enforce procedures, records and data to perform a regular review on the effectiveness of the EMS in order to promote continual environmental improvement $[37,52,53]$.

In September 2015, to guarantee the relevance of the standard for the marketplace, ISO published the ISO 14001:2015 edition. The new edition addresses the latest trends on environmental management and improves the compatibility with other management system standards such as ISO 9001:2015 [54] and an organization's strategic action planning and thinking. The transition deadline for ISO 14001:2015 was 15 September 2018, and by that time all ISO 14001:2004 certificates will no longer be valid. ISO 14001:2015 has been revised in some key aspects, as described by ISO [55]: a greater commitment from leadership; an increased alignment with strategic direction; greater protection for the environment, with a focus on proactive initiatives; more effective communication, driven through a communications strategy; life-cycle thinking, considering each stage of a product or service, from development to end-of-life.

Despite being the main reference in the field of environmental management in organizations, the effectiveness of ISO 14001 is still widely debated by academics and practitioners [23,56]. Studies indicate that the adoption of ISO 14001 does not always translate into environmental and financial benefits, and that a series of drawbacks that hinder potential gains can also be identified [10,57-60]. Studies point out that ISO 14001 brings three types of benefits: environmental performance, efficiency and profitability [61]. However, Whitelaw [62] indicates that the main benefits are generally identified by firms as: gain of a "green image" resulting in gains in market shares; ability to attract new investors; reduction of insurance and prosecution risks; and reduction of costs. This indicates that firms are seeking financial opportunities rather than reducing their environmental impact. In fact, mixed opinions are observable in relation to the ability of ISO 14001 to improve the environmental 
performance of organizations [63]. In this context, two aspects are particularly relevant. First, the fact that implementation of ISO 14001 does not establish absolute requirements for environmental performance means that obtaining certification does not guarantee any improvement that goes beyond the level set by environmental regulations [64]. Second, implementation modes within companies vary enormously. While some firms fully incorporate ISO 14001 into their EMS and aim for continual improvement, others implement the standard without continuously conforming with its requirements and incorporating the necessary practices in their entirety $[39,65]$. Firms do so mostly because of the external pressure of gaining business advantage towards their competitors, and not because they are driven by an internal commitment to improve the environmental performance [66]. For comprehensive reviews on diffusion, determinants, benefits and difficulties in implementation see Nishitani [67], Salim et al. [49], Boiral et al. [23] and Lim and Prakash [68].

\section{ISO 14001 Implementation in China}

The adoption of ISO 14001 has experienced rapid growth in China, leading the country to be the largest adopter of the standard with 137,230 certificates issued as of 2016 , the $39.6 \%$ of the total number of certifications [51]. The Chinese government has strongly contributed to the promotion of the standard since its conception, with the concomitant establishment of the Steering Committee on Environmental Management System Accreditation in 1997 [21]. This growth is concomitant with the increase in sustainability regulations and conspicuous investments in research and development (R\&D) for green technologies described in the first section of this article. Li [69] also states that the ability of the Chinese government to establish national and provincial Environmental Protection Bureaus (EPB) and national certification bodies created a solid structure for the rapid adoption of the ISO 14001 standard. Finally, the growth trend is in agreement with the bilateral Europe-China Trade Agreement, where China is required to create the conditions for a widespread adoption of EMS standard compliant with European environmental trade policies [49]. The rapid growth of the standard in mainland China has attracted researchers' interest, which studied its diffusion [22], mechanisms [24] and motivations for seeking certification [25], impacts on Chinese firm performance [11], effects on environmental regulatory compliance [21], and effects on technological innovation [70]. The adoption of ISO 14001 in China seems mainly driven by the possibility to increase business opportunities rather than an internal desire of improving environmental performance. Zeng et al. [71] reveal that the major motivation for implementing ISO 14001 in China is to seek access to international markets, while Fryxell and colleagues [25] identify that the most relevant aspects are "ensuring regulatory compliance", "enhancing firm's reputation", and "increasing environmental risk management capabilities", suggesting that the adoption of ISO 14001 has a positive feedback on the reputation of Chinese firms. Finally, He et al. [70] recently investigated the effect of ISO 14001 on technological innovation among Chinese listed firm. Findings show that the ISO 14001 standard facilitate technological innovation among firms.

In order to evaluate the certification level of China, the information provided by the ISO survey [51] has been used. Two comparisons are presented, first the number of certificates in absolute terms and then the number of certificates per capita $(\times 1000)$. Figure 1 shows the number of ISO 14001 certificates in absolute terms in China compared with other representative countries and political unions. It can be observed that China has recently become the first country in absolute numbers of certifications, overcoming the European Union (EU) in 2015. This can be explained by the fact that the growth in Europe and China has been different in recent years. In Europe it has slowed down, probably due to the financial situation that effected the European Economic Area at the end of 2009, while in China the number has kept increasing exponentially. Other countries, such as the US and Germany, show a stable number of certificates, while in Japan the number has suffered a decline from 2009 to today. 


\section{Number of ISO 14001 certificates \\ (in absolute terms)}

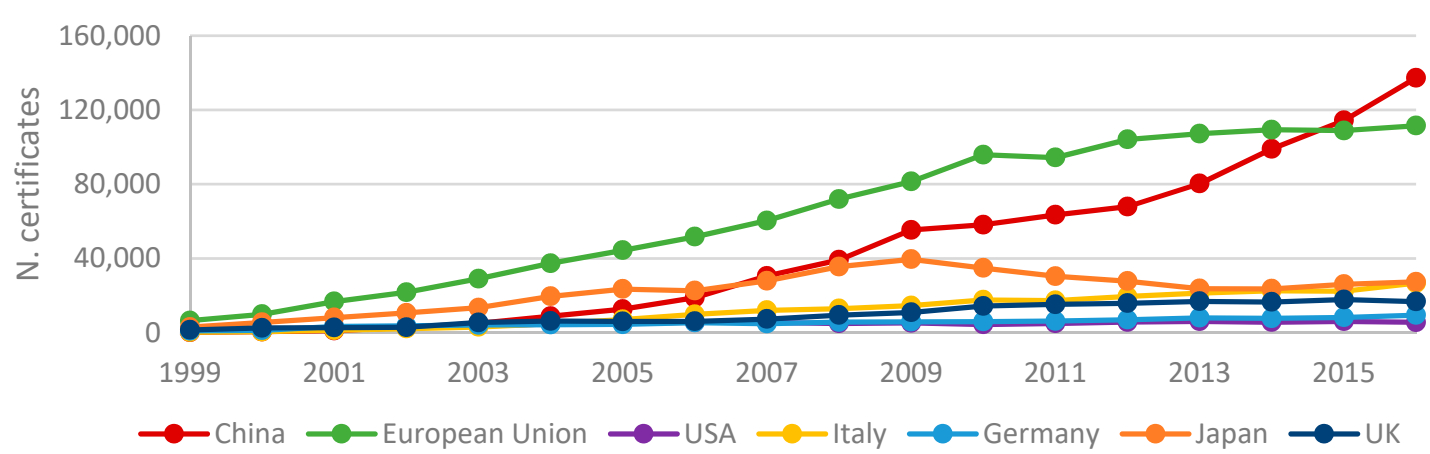

Figure 1. Number of ISO 14001 certificates in the period 1999-2016 for China and other countries and political unions. Data source: [51].

Figure 2 shows the number of certificates per capita $(\times 1000)$ for ISO 14001. In this case, China turns out to be on the opposite side of the ranking, ahead of the United States only. Thus, according to this comparison, it could be stated that China is not a leading country in terms of ISO 14001 certifications, and that the first place in absolute terms can be explained by the higher number of companies that are potentially suitable to be certified compared to other countries. This is a further justification for analyzing the benefits and drawbacks of the ISO 14001 implementation process in China.

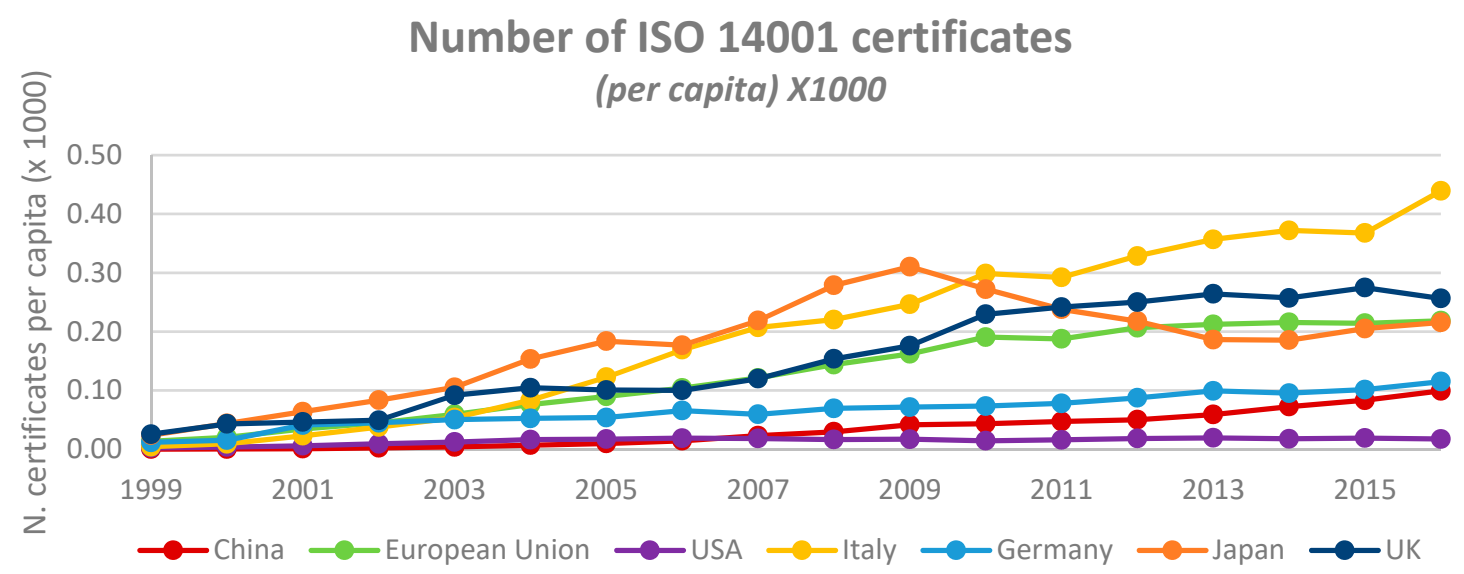

Figure 2. Number of certificates of ISO 14001 per capita $(\times 1000)$. Data source: [51,72].

However, the distribution of ISO 14001 certifications in China has significant heterogeneity at the provincial level. As shown in Figure 3, more than 50\% of the total number of certifications in China is concentrated in the eastern provinces of Guangdong (Pearl River Delta Region), the Yangtze River Delta Region (Jiangsu, Zhejiang and Shanghai), Beijing, Shandong, and Hebei [73]. By contrast, the western provinces of Xinjiang, Gansu, Ningxia, and Qinghai see the lowest implementation of the ISO 14001 standard. This reflects the manufacturing distribution of Chinese industries, which is mainly concentrated in the eastern coastal area of China [74]. 
ISO 14001 certificates in mainland China's provinces (2017)

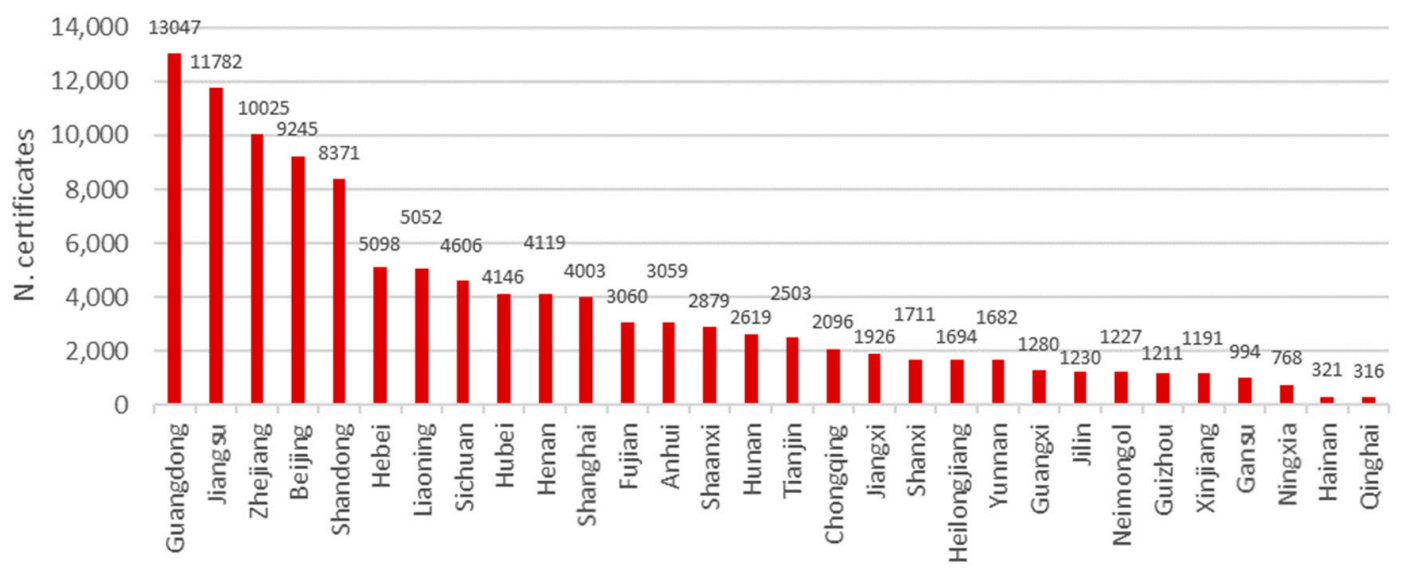

Figure 3. Number of ISO 14001 certificates in mainland China's provinces in the year 2017. Data source: [73].

Using a database from 2001, Cushing and colleagues [24] reported that certifications were mainly concentrated in electronic and electrical equipment $(52 \%)$, machinery equipment $(10 \%)$, chemicals and fibers $(10 \%)$, and construction (5\%). Today the situation has changed, and the adoption of ISO 14001 has spread to other industrial sectors.

Figure 4 shows the distribution of ISO certificates among the 39 Chinese industrial sectors for the year 2017 [73]. The first six sectors account for $64 \%$ of the total number of certificates. The sectors with the major number of certification are the construction sector (28) which accounts for $22 \%$ of certificates, followed by the production of electronic, electrical and optoelectronic equipment (19) with the $10 \%$, wholesale and retail of personal and household goods (29) with the $10 \%$, production of basic metal and metal products (17) with the $8 \%$, technology services (34) with the $7 \%$, and machinery equipment (18) with $6.5 \%$.

ISO 14001 certificates for Chinese industrial sectors (2017)

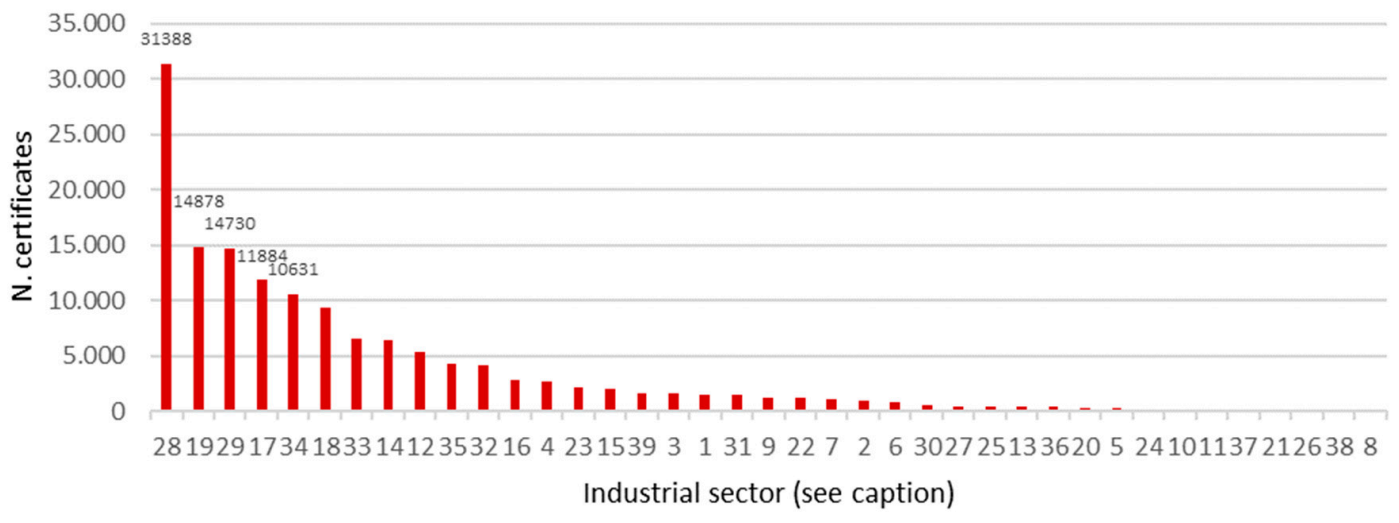

Figure 4. Number of ISO 14001 certificates for China industrial sectors in the year 2017. Data source: [73]. (1) Agriculture, fishery; (2) Mining and quarrying; (3) Food, beverages and tobacco; (4) Textiles and textile products; (5) Leather and leather products; (6) Wood and wood products; (7) Pulp, paper and paper products; (8) Publishing industry; (9) Printing industry; (10) Coke and refined petroleum products; (11) Nuclear fuel; (12) Chemicals and fibers; (13) Pharmaceutical products; (14) Rubber and plastic products; (15) Non-metallic mineral products; (16) Concrete, cement, lime, plaster and others; (17) Basic metal and metal products; (18) Machinery equipment; (19) Electronic, electrical and optoelectronic equipment; (20) Shipbuilding; (21) Aerospace; (22) Other transportation equipment; (23) Other unclassified manufacturing; (24) Recycling of used materials; (25) Power generation and power supply; (26) Gas production and supply; (27) Water production and supply; (28) Construction; 
(29) Wholesale and retail repair of automobiles, motorcycles, personal and household goods; (30) Hotels and restaurants; (31) Transportation, warehousing and communications; (32) Finance, Real Estate, Rental Services; (33) Information Technology; (34) Technology services; (35) Other service; (36) Public administration; (37) Education; (38) Health care and social welfare; (39) Other social services.

\section{Strengths, Weaknesses, Opportunities and Threats (SWOT) Analysis and Result Discussion Based on the Data Collected from Guangdong Province}

In this work, we present the results of a SWOT analysis on ISO 14001 performed by SMEs and MNCs located in the Guangdong province of China, conducted in January 2018, in order to:

- Identify the aspects that describe the degree of utility and the degree of difficulty in the implementation of the standard ISO 14001;

- Assess both the benefits and costs incurred to achieve and maintain the ISO 14001 standard in terms of sustainability (environmental, social and economic), internal processes, relationships with stakeholders, and resource management;

- Understand the prospects of the standard in relation to the rise of new approaches and corporate sustainability paradigms such as corporate social responsibility and circular economy.

SWOT stands for strengths, weaknesses, opportunities and threats. SWOT analysis, which was developed in the 1960s, is a strategic assessment tool for gathering and organizing the information needed to evaluate positive (strengths, opportunities) and negative (weaknesses, threats) elements of a strategy, project, business model, company, or industry [75]. In this study, strengths (S) are referred as those positive attributes of ISO 14001 that can strengthen the performance of a business. Weaknesses $(\mathrm{W})$ describes those negative attributes that can work against the performance of a business. Opportunities $(\mathrm{O})$ are defined as those external positive or attractive factors that ISO 14001 adoption can bring. Threats $(\mathrm{T})$ are those external negative factors originating from the adoption of ISO 14001 that could place the business of an organization at risk. The SWOT analysis tool is usually represented as a table made of four boxes, as presented in Tables 1-4. SWOT analysis was selected because of its simplicity that allows everybody to participate without the need for substantial technical support [76]. On the other hand, the SWOT analysis tool presents also some limitations, such as being an over-simplistic, static and subjective technique [77]. SWOT analysis has been successfully applied in the corporate sustainability field, such as the evaluation of the impact of environmental factors on the competitive strategies of Taiwanese firms [78], assessment of different EMSs in the construction [79], public [80] and educational [81] sectors, and the comparison of different sustainability tools [82].

For this study, 72 participants including top-managers, environmental and CSR managers and EHS auditors from SMEs and MNCs located in Guangdong province were invited to participate to the workshop "New tools and standards to advance and measure corporate sustainability", held in Guangzhou on 26 January 2018. During the workshop, the standard ISO 14001 and other corporate sustainability tools were discussed. The SWOT analysis, planned in the first part of the workshop, was organized as follows: the 72 participants were divided into eight groups of nine people each. A leader with the task of coordinating the discussion among participants was identified for each group. Each group had a whiteboard with the SWOT table depicted on it, where members were asked to write down their considerations. At the end of the SWOT analysis, the leader of each group presented to the other groups the main points identified during the SWOT analysis to provide the starting point for the general discussion among all the participants. The following section presents and discusses the results of the SWOT analysis.

Once the SWOT tables were filled in by the eight groups and merged together, we grouped the aspects of the standards ISO 14001 into four crucial aspects of firms: sustainability, internal processes, relationships with stakeholders, and resource management. The analysis of sustainability aspects was performed to better understand the contribution of ISO 14001 to the sustainability of the company and the regions impacted by their business. The impacts on internal processes were studies to understand the changes, both positive and negative, that the requirements of the standard may 
bring to the activities of Chinese firms. We also evaluated how ISO 14001 can affect the relationship with stakeholders and the disclosure of sensitive information, such as those related to environmental performance. Finally, the impacts on resources and their management has also been assessed to understand the costs and the economic returns that ISO 14001 can bring to Chinese firms. The findings of our study strengthen the importance of the standard in the environmental management of Chinese firms and at the same time highlight limits of the tools and difficulties in its implementation. Results are schematically represented in Tables $1-4$, where strengths, weaknesses, opportunities and threats identified by the participants are listed. Tables also indicate how many groups have identified each element (the absence of the number indicates that only one group has identified that element).

\subsection{Sustainability}

Table 1 refers to those impacts of ISO 14001 that affect sustainability aspects of the company and the surroundings. Several insights can be drawn from the table. Companies recognize a positive contribution of the standard in raising environmental awareness, identifying relevant environmental aspects, and improving compliance with legal requirements. This is confirmed by several studies that have identified positive impacts of ISO 14001 on environmental management practices $[23,46,83]$. However, some participants felt the lack of guidelines regarding the selection and implementation of environmental protection measures as a limit of the tool. Moreover, two groups criticized the voluntary aspect of the standard, pointing out that a legally binding tool for EMSs would be more effective for the improvement of environmental performance of firms.

On a positive note, it also comes to light that firms do not look at sustainability as a mere environmental problem anymore. In fact, one group lamented that ISO 14001 does not improve the overall sustainability of a firm, but only its environmental pillar. Being sustainably responsible means also investing in human capital and establishing solid relationships with stakeholders [84]. Also, it was stated that ISO 14001 does not integrate completely with other sustainability paradigms such as the circular economy and does not require the strict implementation of life cycle assessment approaches even though it requires firms to adopt a life cycle perspective. This lack of synergies among sustainability standards and tools is also confirmed in recent literature. For example, Pauliuk [85] states that the circular economy standard BS 8001:2017 lacks an exhaustive description and support with regard to synergies with EMSs standards such as ISO 14001. Participants also identified a series of opportunities for both firms and the society. For firms, ISO 14001 can encourage the implementation of new sustainable business models and green technologies, improve environmental communication, reduce emissions, save energy, and design more sustainable products (eco-design principles). At the same time, ISO 14001 can indirectly increase public attention to environmental issues, improve the health of citizens and contribute to a cleaner environment. Finally, identified threats are mainly related to the fact that the main objective of firms has become the certification itself, mainly driven by external pressure (e.g., clients requiring the certification), and not from an internal commitment of the firms to improve their environmental performance [21]. This is reflected also in other studies. For example, Yin and Ma [64] found that ISO 14001 certification in Chinese manufacturing firms was mainly sought in order to access advanced international markets rather than improving environmental performance. 
Table 1. Sustainability related aspects of ISO 14001 that have an effect on firms, society and the environment. Tables also indicate how many groups have identified each element (the absence of the number indicates that only one group has identified that element).

\begin{tabular}{|c|c|}
\hline \multicolumn{2}{|c|}{ Sustainability } \\
\hline Strengths: & Weaknesses: \\
\hline $\begin{array}{l}\text { - Promotes the idea of environmental protection and } \\
\text { environmental awareness in a company. (4) } \\
\text { - Provides guidance on how to improve the } \\
\text { environmental sustainability of a company. (3) } \\
\text { - Provides guidance on evaluating and reducing the } \\
\text { environmental and legal risks of a company. (2) } \\
\text { - Provides guidance on the identification of relevant } \\
\text { environmental aspects of a company. }\end{array}$ & $\begin{array}{l}\text { - } \quad \text { Lacks exhaustive guidelines on environmental } \\
\text { protection measures. (2) } \\
\text { - } \quad \text { Not legally binding. (2) } \\
\text { Does not provide in-depth guidance on how to } \\
\text { promote and integrate environmental aspects in } \\
\text { a company's strategy. (2) } \\
\text { - Does not improve the overall sustainability of } \\
\text { a company. } \\
\text { Does not fully integrate circular } \\
\text { economy principles. } \\
\text { Mentions life cycle thinking but does not require } \\
\text { life cycle assessment (LCA). }\end{array}$ \\
\hline
\end{tabular}

Opportunities: Threats:

- Can improve the environmental communication of companies. (2)

- Nationwide promotion of green and sustainable development. (2)

- More public attention to environmental protection. (2)

- Improves the health of residents and of the cities. (2)

- Promotes the implementation of environmental technologies.

- Development of green economy business models.

- Makes product more environmentally friendly (eco-design).

- Promotes energy saving and emission reduction.

- The aim of company has become the certification itself and not the protection of the environment. (2)

- Certification comes from external pressure, not self-driven.

\subsection{Internal Processes}

Table 2 refers to those technical aspects of the standard that influence the internal processes of firms. All the groups except one pointed out the benefits provided by the standardization of environmental management processes [86-88]. It is demonstrated that standardization contributes to a better handling of environmental issues and to better organizational environmental performance [89]. Other strengths are related to the wide applicability of the standard in all sectors and countries, the necessity to adopt measurable indicators to measure the improvement of environmental performance, and the presence of a third-party assessment to obtain certification. Differences of opinion were observed regarding the support of ISO 14001 in the integration of environmental management processes in the overall management of a firm. Three groups expressed a positive opinion, while two groups pointed out that changes required to integrate the standard clash with a solidified management thinking that does not see environmental aspects as an essential part of a firm's strategy. The integration of environmental practices required by ISO 14001 with daily activities is an essential problem identified in different studies [90,91].

Other weaknesses identified by more than one group are the amount of paperwork and additional activities at different levels of the company in order to maintain the certification, as identified also in previous studies [92,93], the difficulty of implementing environmental protection activities at all levels of the company, and the absence of methods to identify who has a better environmental performance among certified companies. In fact, ISO 14001 does not recognize organizations for having reached a certain level of environmental performance, rather recognizing those that have implemented an EMS for the continual improvement of their environmental performance. Participants also lamented the absence of aspects that consider the difference among countries and sectors and the level of ability of 
a company, which can bring a different understanding and interpretation of the standard in the first phases of implementation.

Identified opportunities relates to the benefits of ISO 14001 on product and process innovation and to the improvement of the overall efficiency of a company if all requirements of the standards are implemented. He and Shen [70], investigate how the ISO 14001 certification shapes corporate technological innovation in Chinese firms. They conclude that the certification of ISO 14001 facilitates corporate technological innovation and improves resource management of companies, thus enabling them to better invest in R\&D and innovation activities. However, one group of participants argued that standardization can limit innovation since companies are forced to follow specific guidelines.

The main threats are related to the devaluation of the standard. Participants stated that the government focus on legally binding standards (i.e., emission standards), and that ISO 14001 has become a mere formality that a company implements to access international markets. Moreover, new sustainability standards continuously emerge, and it is becoming increasingly difficult to integrate them. Other identified threats are also related to conflicts of interest between auditors and auditees (i.e., firms) and issues of organizational honesty. The credibility of the ISO 14001 standard has been under scrutiny since its inception and has been questioned by several actors among scholars [94,95], government agencies [96], environmental groups [97], and the industry itself [98].

Table 2. Technical aspects of ISO 14001 that have an effect on the internal processes of firms. Tables also indicate how many groups have identified each element (the absence of the number indicates that only one group has identified that element).

\begin{tabular}{|c|c|}
\hline \multicolumn{2}{|c|}{ Internal Processes } \\
\hline Strengths: & Weaknesses: \\
\hline $\begin{array}{l}\text { - Standardization of environmental management } \\
\text { processes. (7) } \\
\text { Allows the integration of environmental } \\
\text { management in the overall management of the } \\
\text { enterprise. (3) } \\
\text { - Widely applicable in all sectors and countries (2) } \\
\text { - Requires measurable indicators in order to } \\
\text { monitor continuous } \\
\text { environmental improvement. } \\
\text { Requires a third-party assessment } \\
\text { for certification. }\end{array}$ & $\begin{array}{l}\text { - } \quad \text { Requires too much paperwork to maintain the } \\
\text { certification. (3) } \\
\text { - } \quad \text { Clashes with a solidified management thinking. (2) } \\
\text { It does not provide a method to differentiate } \\
\text { organization based on their level of environmental } \\
\text { performance. (2) } \\
\text { - Environmental protection measures are difficult to } \\
\text { implement at all levels of a company. (2) } \\
\text { - It does not consider the differences in } \\
\text { implementation that exist among various countries } \\
\text { and sectors. } \\
\text { It does not consider the level of ability } \\
\text { of companies } \\
\text { Understanding is not always clear, which leads to a } \\
\text { different interpretation of the standard }\end{array}$ \\
\hline
\end{tabular}

- $\quad$ The government focuses on legally binding emission standards; it does not care whether a company has ISO 14001 or not. (4)

- Obtaining ISO 14001 has become a formality in China (devaluation of the standard). (4)

- Stimulates product and process innovation.

- Improves overall efficiency of the company if all aspects are implemented.

- New sustainability standards emerge continuously. It is becoming increasingly difficulty to integrate them. (2)

- Standardization does not help to promote innovation.

- Credibility of auditors: unevenness of ability and honesty.

- A company might fake everything just to get the certification. 


\subsection{Stakeholder Engagement}

Table 3 refers to those aspects that influence a firm's relationships with stakeholders. Identified strengths of the standard related to the fact that it requires participation at all levels of the company, and strongly encourages an active commitment of the top management. Findings from previous studies indicate that the involvement and leading role played by the top management plays a key role in implementing and maintaining the standard ISO 14001 through the allocation of sufficient time and resources to operate the environmental management system [65,99,100]. Moreover, studies point out that participating in the certification process contributes to increase the sustainability performance of firms and gives advantages over competitors as they address stakeholder concerns on triple-bottom-line issues [56]. Finally, ISO 14001 is recognized by customers and national and international institutions. On the other hand, the identified weaknesses highlight the lack of supervision from a governmental authority and the difficulty of involving the whole supply-chain.

Participants identified a series of opportunities that ISO 14001 brings to relationships with stakeholders of a firm. First, four groups stated that the standard contributes to strengthening relationships with customers and suppliers, especially international ones. Second, it increases collaboration and participation among employees, as identified also in other studies $[89,101]$. Third, it improves the reputation of the company and its social license to operate. ISO 14001 also contributes to considering the interests of a firm's stakeholders, motivate suppliers in adopting environmental management measures, and benefits communication along the supply chain.

Threats can relate to the low interest of the top management in being involved. In fact, although top management commitment is required by the standard, its level of commitment can vary greatly, with consequent differences in the effective implementation of ISO $14001[39,65]$. Two groups also indicated that firms feel pressured by clients to get and maintain certification, or that clients already demand environmental requirements that exceed ISO 14001. Studies indicate that this pressure can lead to a superficial adoption of the standard $[90,102]$. Companies that are concerned with the final consumers of their products also say that the standard has a low recognition among them. Finally, firms' reputations can be damaged if ISO 14001 is lost or suspended because of violation of the standard. Studies indicate that improved image and reputation are one of the most common benefits of the firms $[103,104]$. Consequently, a loss of the certification can severely harm the image of a company in the eyes of its stakeholders.

Table 3. Aspects of ISO 14001 that have an effect on firms' relationship with stakeholders. Tables also indicate how many groups have identified each element (the absence of the number indicates that only one group has identified that element).

\begin{tabular}{cll}
\hline \multicolumn{1}{c}{ Stakeholder Engagement } \\
\hline - $\begin{array}{l}\text { Participation at all levels of the company. (2) } \\
\text { - Requires the commitment of top-management. } \\
\text { - Recognized by customers. } \\
\text { Recognized by national and international institutions. }\end{array}$ & $\begin{array}{l}\text { Weaknesses: } \\
\text { Opportunities: }\end{array}$ & $\begin{array}{l}\text { Does not provide require the supervision of } \\
\text { a governmental authority. }\end{array}$ \\
\hline
\end{tabular}

- Strengthen relationships with customers and suppliers, especially international ones. (4)

- Increases collaboration and participation among employees. (3)

- Publicly demonstrates the commitment to environmental protection: improved reputation of the company and social license to operate. (2)

- Pushes a company to consider the interests of its stakeholders.

- Can motivate suppliers in adopting environmental management measures.

- $\quad$ Top-management may not care. (2)

- $\quad$ Strong pressure to get certification from stakeholders (e.g., international clients). (2)

- Clients environmental requirements may exceed ISO 14001.

- Low recognition from the Chinese consumer.

- Reputation is damaged if certification is lost or suspended for some violation of the standard.

- Benefits supply chain communication. 


\subsection{Resource Management}

Table 4 refers to those aspects that have an influence on a firm's internal resources. The standard ISO 14001 has been described has a useful tool for a better management of internal resources of a company. It can also bring opportunities in terms of new customers, especially from western countries, reduce legal risks and related expenses, overall costs of execution, and environmental taxation. Finally, it gives access to external financial support and subsidies from governmental bodies.

On the other hand, resources, in terms of money, people and time, that are required to be compliant with the standard can be high, especially for SMEs. This can lead to a series of threats to companies: increased management and production costs such as the need to install environmental protection and monitoring equipment (e.g., air emission abatement systems, water pollution control, waste treatment and disposal technologies) and the need to reinvent production activities or redesign products. This can become too economically risky for those small companies where the financial return might be too low compared to costs and risks of implementation of the standard. Also, companies tend to focus on short-term profit maximization, which is at odds with the principles of sustainability. As a result, costs related to environmental protection measure are the first to be cut in the event of cost-saving interventions. Finally, if the certification is lost or suspended, the financial resources of the company might be affected due to a loss of reputation, as mentioned in the previous section.

Table 4. Aspects of ISO 14001 that have an effect on the resources of firms. Tables also indicate how many groups have identified each element (the absence of the number indicates that only one group has identified that element).

\begin{tabular}{|c|c|}
\hline \multicolumn{2}{|c|}{ Resource Management } \\
\hline Strengths: & Weaknesses: \\
\hline $\begin{array}{l}\text { - It provides guidance on the management } \\
\text { of resources. }\end{array}$ & $\begin{array}{l}\text { - The costs related to implementation and } \\
\text { certification fee are too high for small and } \\
\text { medium companies. }\end{array}$ \\
\hline Opportunities: & Threats: \\
\hline $\begin{array}{ll}\text { - } & \text { Brings more customers, especially from foreign } \\
\text { - } & \text { Redustomers. (3) } \\
\text { - } & \text { Reduces overall costs in the long-term. (2) } \\
\text { - } & \text { Reduces environmental taxation. } \\
\text { - } & \text { Helps to gain financial support and subsidies } \\
\text { from government. }\end{array}$ & $\begin{array}{l}\text { Increases management and production costs } \\
\text { (environmental protection technology, design of } \\
\text { new products). (4) } \\
\text { - Too economically risky for small companies } \\
\text { (costs in terms of change and maintenance). } \\
\text { - } \quad \begin{array}{l}\text { Financial return can be too low compared to the } \\
\text { initial financial investment. }\end{array} \\
\text { - The company focuses on financial benefits and } \\
\text { environmental protection is easy to marginalize. } \\
\text { - Damage if certification is lost or suspended for } \\
\text { some violation of the standard. }\end{array}$ \\
\hline
\end{tabular}

\section{Conclusions}

The purpose of this study was to analyze the opinion of a group of SMEs and MNCs of Guangdong province in China about the voluntary standard ISO 14001, whose aim is to set out the criteria for an effective EMS. China is the largest and fastest growing adopter of ISO 14001, with Guangdong province being the main contributor in the country. By performing a SWOT analysis, we analyzed four aspects relevant to Chinese firms: sustainability, internal processes, stakeholder engagement, and resource management. Our results indicate that Chinese companies fully embrace ISO 14001 and recognize the necessity of a standardized approach to identify environmental aspects. ISO 14001 contributes to the promotion and adoption of environmental management principles at the company level, contributing to improving the environmental footprint of industrial areas, and reducing the negative effects on nearby communities. They also highlighted the importance of 
ISO 14001 in supporting companies in the adoption of a system thinking approach and in improving the communication with stakeholders and the disclosure of sensitive environmental information. On the other hand, they expressed a number of concerns that should be further investigated in future studies. Concerns were raised about the cost of implementation and certification, which can be considered too risky for SMEs. Moreover, participants pointed out a devaluation of the standard, that is now used mainly as necessary way to access international markets. The internal drive of a company to reduce its negative impacts on the environment seem to be a secondary reason for implementation of the standard. Another relevant aspect is that the interviewed Chinese companies are going beyond the sole implementation of EMSs for the management of environmental aspects, and this is mainly at the request of external stakeholders. They are starting to recognize the importance of sustainability tools such as LCA and other sustainability paradigms such as circular economy and CSR, and demanding changes that can accommodate the integration of all the tools and standards that regulate the different aspects of sustainability in a company. This lack of integration with other sustainability tools should be taken into account in newer versions of the standard, as well as the absence of performance requirements and the lack of a mandatory set of indicators that would allow for differentiation between good and bad implementation of the standard, as indicated also in other studies [105].

Our results are consistent with previous SWOT analysis on ISO 14001 in Europe [106,107], India [79] and North America [108]. Specifically, common points in the strengths of the standard are the systemic approach to the management of environmental aspects, its flexibility of adoption, the third-party evaluation and the required involvement of the entire organization. Identified common weaknesses relate to the difficulty of assessing environmental impacts at the supply-chain level, the absence of performance standards, the amount of paperwork and the cost of certification. Some identified opportunities are also shared, such as the improvement of reputation and trust, the reduction of environmental risks and costs (e.g., interruption of activities, penalties and sanctions, etc.), and improved communication on environmental performance between customer and supplier. Finally, shared threats relate to the low recognition of certification from relevant stakeholders (i.e., governments, control bodies, financing bodies, etc.), the end of public funding for the certification, corruption among auditors, and the focus on certification and not on the improvement of environmental performance. The most marked divergences are related to a different perception in the threat generated by the risk of public disclosure of incriminating environmental information, as pointed out in Yiridoe et al. [108]. In our study, no participants highlighted this threat. Also, despite confirming our findings on the difficulty of implementation of ISO 14001 at the supply-chain level, Gnoni and Lanzilotto [106] also identified benefits and opportunities. Specifically, they acknowledge that the standardized framework of ISO 14001 allows control of the environmental impact of each actor of the supply-chain and promotes the implementation of environmental programs at the supply-chain level.

In this work, the number of participants (72) is relatively small compared to the number of companies in Guangdong province, which results in some limitations to the work. First, we have not controlled for specific sizes or industry type (e.g., construction, textile, electronics), which would have been useful. Second, the SWOT analysis was performed in groups and not independently. If, on the one hand, it has stimulated the discussion, it may have also hidden the opinions of some participants. Finally, the level of awareness on EMSs among the workshop participants was uneven and not possible to quantitatively address. This might have biased the results by highlighting the factors of the participants with more expertise. The above points are interesting directions for future study when more data is available. However, apart from its theoretical contribution, the results of the study can have positive implications for practitioners, researchers and policy-makers. Accordingly, future studies could deepen the analysis by adding further categories of classification factors to the SWOT analysis (strengths, weaknesses, internal opportunities, internal threats, stimulants, counter stimuli, external opportunities, external threats), as proposed by Nazarko and colleagues [109]. Moreover, the use of the qualitative results obtained in this and related studies could provide valuable inputs to direct relevant 
quantitative analysis aiming at providing useful data for computing performance indicators (e.g., return on investment (ROI)) and comparing different alternatives for environmental and sustainable management. The paper's findings can help sustainability and environmental managers to anticipate potential difficulties in the implementation of the standard and maximize benefits that ISO 14001 can bring to a company in the form of improved efficiency of internal processes, increased international reputation and trust, and reduced legal and environmental risks. The paper also provides a description of topics companies need to pay attention to in order to maintain and improve their sustainability performance. Future studies could analyze the different perceptions of ISO 14001 in China based on the industrial sector and provinces, and test whether the findings are in line with the results of this paper.

Author Contributions: M.P. conceived of the research, undertook data collection and analysis, and drafted the article. C.S. contributed to the manuscript development. A.C. conceived of the research, contributed to the research positioning and revised the article. X.W. contributed to the interpretation of results. A.M. played an important role in proof-reading. All authors read and approved the final manuscript.

Funding: This research was funded by the MEDIUM project (New pathways for sustainable development in Chinese MEDIUM size-cities) grant number ICI+/2014/348-005 and the APC was funded by the project Study on Urban Spatial Growth From The Viewpoint of Resource Efficiency, grant number 40971097, National Natural Science Foundation of China.

Acknowledgments: This research work was conducted in the context of the MEDIUM project (New pathways for sustainable development in Chinese MEDIUM size-cities). The author would like to acknowledge the support of the French National Center for Scientific Research (CNRS) and the European Centre for Living Technology (ECLT) of Ca' Foscari University of Venice, and to thank MEDIUM partners, in particular Sun Yat-Sen University. The MEDIUM project has received funding from the European Union under the External actions of the EU-Grant Contract ICI+/2014/348-005.

Conflicts of Interest: The authors declare no conflict of interest.

\section{References}

1. Zhou, C.; Shi, C.; Wang, S.; Zhang, G. Estimation of eco-efficiency and its influencing factors in Guangdong province based on Super-SBM and panel regression models. Ecol. Indic. 2018, 86, 67-80. [CrossRef]

2. Bao, M. The Evolution of Environmental Policy and its Impact in the People's Republic of China. Conserv. Soc. 2006, 1, 36-54.

3. Zhang, K.M.; Wen, Z.G. Review and challenges of policies of environmental protection and sustainable development in China. J. Environ. Manag. 2008, 88, 1249-1261. [CrossRef] [PubMed]

4. Wang, J. China's national cleaner production strategy. Environ. Impact Assess. Rev. 1999, 19, 437-456. [CrossRef]

5. Wang, L. The changes of China's environmental policies in the latest 30 years. Procedia Environ. Sci. 2010, 2, 1206-1212. [CrossRef]

6. Matsuno, H. China's Environmental Policy:Its Effectiveness and Suggested Approaches for Japanese Companies. Nomura Res. Insitute Pap. 2009, 140, 1-13.

7. Zeng, S.X.; Liu, H.C.; Tam, C.M.; Shao, Y.K. Cluster analysis for studying industrial sustainability: An empirical study in Shanghai. J. Clean. Prod. 2008, 16, 1090-1097. [CrossRef]

8. Geng, Y.; Cote, R. Environmental Management Systems at the Industrial Park Level in China. Environ. Manag. 2003, 31, 784-794. [CrossRef] [PubMed]

9. Garza-Reyes, J.A.; Yu, M.; Kumar, V.; Upadhyay, A. Total quality environmental management: Adoption status in the Chinese manufacturing sector. TQM J. 2018, 30, 2-19. [CrossRef]

10. Li, B.; Wu, K. Environmental Management System Adoption and the Operational Performance of Firm in the Textile and Apparel Industry of China. Sustainability 2017, 9, 992. [CrossRef]

11. He, W.; Liu, C.; Lu, J.; Cao, J. Impacts of ISO 14001 adoption on firm performance: Evidence from China. China Econ. Rev. 2015, 32, 43-56. [CrossRef]

12. Dong, L.; Li, Y.; Wang, P.; Feng, Z.; Ding, N. Cleaner production of monosodium glutamate in China. J. Clean. Prod. 2018, 190, 452-461. [CrossRef]

13. Li, X.; Hamblin, D. Factors impacting on cleaner production: Case studies of Chinese pharmaceutical manufacturers in Tianjin, China. J. Clean. Prod. 2016, 131, 121-132. [CrossRef] 
14. Mathews, J.A.; Tan, H.; Hu, M.-C. Moving to a Circular Economy in China: Transforming Industrial Parks into Eco-industrial Parks. Calif. Manag. Rev. 2018, 60, 157-181. [CrossRef]

15. Li, Y.; Ma, C. Circular economy of a papermaking park in China: A case study. J. Clean. Prod. 2015, 92, 65-74. [CrossRef]

16. Thai, R.; Liu, G. Eco-design pilot project in China-Monsoon offer 2 upgrade. IOP Conf. Ser. Earth Environ. Sci. 2017, 94, 012170. [CrossRef]

17. Yu, J.; Hills, P.; Welford, R. Extended producer responsibility and eco-design changes: Perspectives from China. Corp. Soc. Responsib. Environ. Manag. 2008, 15, 111-124. [CrossRef]

18. Li, G.; Shao, S.; Zhang, L. Green supply chain behavior and business performance: Evidence from China. Technol. Forecast. Soc. Chang. 2018, in press. [CrossRef]

19. Khan, S.A.R.; Dong, Q.; Zhang, Y.; Khan, S.S. The Impact of Green Supply Chain on Enterprise Performance: In the Perspective of China. J. Adv. Manuf. Syst. 2017, 16, 263-273. [CrossRef]

20. Chung, S.S.; Fryxell, G.E.; Lo, C.W.H. Corporate Environmental Policy Statements in Mainland China: To What Extent Do They Conform to ISO 14000 Documentation? Environ. Manag. 2005, 35, 468-482. [CrossRef] [PubMed]

21. McGuire, W. The effect of ISO 14001 on environmental regulatory compliance in China. Ecol. Econ. 2014, 105, 254-264. [CrossRef]

22. Qi, G.Y.; Zeng, S.X.; Tam, C.M.; Yin, H.T.; Wu, J.F.; Dai, Z.H. Diffusion of ISO 14001 environmental management systems in China: Rethinking on stakeholders' roles. J. Clean. Prod. 2011, 19, 1250-1256. [CrossRef]

23. Boiral, O.; Guillaumie, L.; Heras-Saizarbitoria, I.; Tene, C.V.T. Adoption and Outcomes of ISO 14001: A Systematic Review. Int. J. Manag. Rev. 2018, 20, 411-432. [CrossRef]

24. Cushing, K.K.; McGray, H.; Lu, H. Understanding ISO 14001 adoption and implementation in China. Int. J. Environ. Sustain. Dev. 2005, 4, 246. [CrossRef]

25. Fryxell, G.E.; Lo, C.W.; Chung, S.S. Influence of Motivations for Seeking ISO 14001 Certification on Perceptions of EMS Effectiveness in China. Environ. Manag. 2004, 33, 239-251. [CrossRef] [PubMed]

26. Lau, A.K.W.; Lee, P.K.C.; Cheng, T.C.E. An empirical taxonomy of corporate social responsibility in China's manufacturing industries. J. Clean. Prod. 2018, 188, 322-338. [CrossRef]

27. Yin, J.; Jamali, D. Strategic Corporate Social Responsibility of Multinational Companies Subsidiaries in Emerging Markets: Evidence from China. Long Range Plan. 2016, 49, 541-558. [CrossRef]

28. Dajian, Z. Background, Pattern and Policy of China for Developing Circular Economy. Chin. J. Popul. Resour. Environ. 2008, 6, 3-8. [CrossRef]

29. Zhu, J.; Fan, C.; Shi, H.; Shi, L. Efforts for a Circular Economy in China: A Comprehensive Review of Policies. J. Ind. Ecol. 2018. [CrossRef]

30. Fonseca, L.M.; Domingues, J.P.; Pereira, M.T.; Martins, F.F.; Zimon, D. Assessment of circular economy within Portuguese organizations. Sustainability 2018, 10, 2521. [CrossRef]

31. Büthe, T.; Mattli, W. The New Global Rulers: The Privatization of Regulation in the World Economy; Princeton University Press: Princeton, NJ, USA, 2011.

32. Tuczek, F.; Castka, P.; Wakolbinger, T. A review of management theories in the context of quality, environmental and social responsibility voluntary standards. J. Clean. Prod. 2018, 176, 399-416. [CrossRef]

33. ISO. ISO 14001:2015-Environmental Management Systems-Requirements with Guidance for Use; International Organization for Standardization: Geneva, Switzerland, 2015.

34. EC. Regulation (EC) No 1221/2009 of the European Parliament and of the Council of 25 November 2009 on the Voluntary Participation by Organisations in a Community Eco-Management and Audit Scheme (EMAS), Repealing Regulation (EC) No 761/2001 and Commission Deci; European Commission: Bruxelles, Belgium, 2009.

35. BSI. Environmental Management Systems—Phased Implementation-Guide; British Standards Institution: London, UK, 2016.

36. Psomas, E.L.; Fotopoulos, C.V.; Kafetzopoulos, D.P. Motives, difficulties and benefits in implementing the ISO 14001 Environmental Management System. Manag. Environ. Qual. Int. J. 2011, 22, 502-521. [CrossRef]

37. Zutshi, A.; Sohal, A. A study of the environmental management system (EMS) adoption process within Australasian organisations-2. Role of stakeholders. Technovation 2004, 24, 371-386. [CrossRef]

38. Teng, M.-J.; Wu, S.-Y. Sustainable Development and Competitive Advantages-Utilizing Matching to Overcome Sample Selection Bias. Corp. Soc. Responsib. Environ. Manag. 2017. [CrossRef] 
39. Iatridis, K.; Kesidou, E. What Drives Substantive Versus Symbolic Implementation of ISO 14001 in a Time of Economic Crisis? Insights from Greek Manufacturing Companies. J. Bus. Ethics 2018, 148, 859-877. [CrossRef]

40. Lyon, T.P.; Maxwell, J.W. Self-regulation, taxation and public voluntary environmental agreements. J. Public Econ. 2003, 87, 1453-1486. [CrossRef]

41. ISO. ISO 9001:2015-Quality Management Systems—Requirements with Guidance for Use; International Organization for Standardization: Geneva, Switzerland, 2015.

42. ISO. ISO 45001:2018-Occupational Health and Safety Management Systems-Requirements with Guidance for Use; International Organization for Standardization: Geneva, Switzerland, 2018.

43. ISO. ISO 22000:2018 —Food Safety Management Systems_Requirements for Any Organization in the Food Chain; International Organization for Standardization: Geneva, Switzerland, 2018.

44. Karapetrovic, S.; Jonker, J. Integration of standardized management systems: Searching for a recipe and ingredients. Total Qual. Manag. Bus. Excell. 2003, 14, 451-459. [CrossRef]

45. Zeng, S.X.; Xie, X.M.; Tam, C.M.; Shen, L.Y. An empirical examination of benefits from implementing integrated management systems (IMS). Total Qual. Manag. Bus. Excell. 2011, 22, 173-186. [CrossRef]

46. Domingues, P.; Sampaio, P.; Arezes, P.M. Integrated management systems assessment: A maturity model proposal. J. Clean. Prod. 2016, 124, 164-174. [CrossRef]

47. Karapetrovic, S.; Willborn, W. Integration of Quality and Environmental Management Systems. TQM Mag. 1998, 10, 201-213. [CrossRef]

48. Nishitani, K. Demand for ISO 14001 adoption in the global supply chain: An empirical analysis focusing on environmentally conscious markets. Resour. Energy Econ. 2010, 32, 395-407. [CrossRef]

49. Salim, H.K.; Padfield, R.; Hansen, S.B.; Mohamad, S.E.; Yuzir, A.; Syayuti, K.; Tham, M.H.; Papargyropoulou, E. Global trends in environmental management system and ISO14001 research. J. Clean. Prod. 2018, 170, 645-653. [CrossRef]

50. Da Fonseca, L.M.C.M. ISO 14001:2015: An improved tool for sustainability. J. Ind. Eng. Manag. 2015, 8, 37-50.

51. ISO. ISO Survey 2016; International Organization for Standardization: Geneva, Switzerland, 2017.

52. Wright, T. IMS-Three into one will go!: The advantages of a single integrated quality, health and safety, and environmental management system. Qual. Assur. J. 2000, 4, 137-142. [CrossRef]

53. Zeng, S.X.; Shi, J.J.; Lou, G.X. A synergetic model for implementing an integrated management system: An empirical study in China. J. Clean. Prod. 2007, 15, 1760-1767. [CrossRef]

54. Fonseca, L.; Domingues, J. Exploratory Research of ISO 14001:2015 Transition among Portuguese Organizations. Sustainability 2018, 10, 781. [CrossRef]

55. ISO. The Newly Revised ISO 14001 Is Here. 2015. Available online: https://www.iso.org/news/2015/09/ Ref1999.html (accessed on 15 May 2018).

56. Wang, X.; Lin, H.; Weber, O. Does adoption of management standards deliver efficiency dain in firms' pursuit of sustainability performance? An empirical investigation of chinese manufacturing firms. Sustainablity 2016, 8, 694. [CrossRef]

57. Castka, P.; Corbett, C.J. Management Systems Standards: Diffusion, Impact and Governance of ISO 9000, ISO 14000, and Other Management Standards. Found. Trends ${ }^{\circledR}$ Technol. Inf. Oper. Manag. 2015, 7, 161-379. [CrossRef]

58. Gawaikar, V.; Bhole, A.; Lakhe, R. Measuring the Impact of ISO 14001 Implementation. Pol. J. Environ. Stud. 2018, 27, 637-646. [CrossRef]

59. Boiral, O.; Henri, J.-F. Modelling the impact of ISO 14001 on environmental performance: A comparative approach. J. Environ. Manag. 2012, 99, 84-97. [CrossRef] [PubMed]

60. Montabon, F.; Melnyk, S.A.; Sroufe, R.; Calantone, R.J. ISO 14000: Assessing Its Perceived Impact on Corporate Performance. J. Supply Chain Manag. 2000, 36, 4-16. [CrossRef]

61. Di Noia, A.E.; Nicoletti, G.M. ISO 14001 certification: Benefits, costs and expectations for organization. Stud. Oeconomica Posnaniensia 2016, 4, 94-109. [CrossRef]

62. Whitelaw, K. ISO 14001 Environmental Systems Handbook; Routledge: London, UK, 2004.

63. Potoski, M.; Prakash, A. Covenants with weak swords: ISO 14001 and facilities' environmental performance. J. Policy Anal. Manag. 2005, 24, 745-769. [CrossRef]

64. Yin, H.; Ma, C. International integration: A hope for a greener China? Int. Mark. Rev. 2009, 26, 348-367. [CrossRef] 
65. Chowdhury, M.; Prajogo, D.; Jayaram, J. Comparing symbolic and substantive implementation of international standards-The case of ISO 14001 certification. Australas. J. Environ. Manag. 2018, 20, 1-23. [CrossRef]

66. Chavan, M. An appraisal of environment management systems: A competitive advantage for small businesses. Manag. Environ. Qual. Int. J. 2005, 16, 444-463. [CrossRef]

67. Nishitani, K. An empirical study of the initial adoption of ISO 14001 in Japanese manufacturing firms. Ecol. Econ. 2009, 68, 669-679. [CrossRef]

68. Lim, S.; Prakash, A. Voluntary regulations and innovation: The Case of ISO 14001. Public Adm. Rev. 2014, 74, 233-244. [CrossRef]

69. Li, Y. China powerhouse embraces ISO 14001 certification. ISO Manag. Syst. 2008, 8, 25-26.

70. He, W.; Shen, R. ISO 14001 Certification and Corporate Technological Innovation: Evidence from Chinese Firms. J. Bus. Ethics 2017. [CrossRef]

71. Zeng, S.X.; Tam, C.M.; Tam, V.W.Y.; Deng, Z.M. Towards implementation of ISO 14001 environmental management systems in selected industries in China. J. Clean. Prod. 2005, 13, 645-656. [CrossRef]

72. Bank, W. World Bank. 2018. Available online: http:/ / www.worldbank.org (accessed on 20 May 2018).

73. CNAS. 2017 Certification Body Recognition Annual Report; CNAS: Beijing, China, 2018.

74. Berkeley Sourcing Group. Map of China Manufacturing Distribution. 2016. Available online: http://www. berkeleysg.com/china-manufacturing-distribution-map/ (accessed on 6 September 2018).

75. Teece, D.J. SWOT Analysis. In The Palgrave Encyclopedia of Strategic Management; Palgrave Macmillan: London, UK, 2017; pp. 1-2.

76. Sørensen, L.; Vidal, R.V.V.; Engström, E. Using soft OR in a small company-The case of Kirby. Eur. J. Oper. Res. 2004, 152, 555-570. [CrossRef]

77. Panagiotou, G.; van Wijnen, R. The 'telescopic observations' framework: An attainable strategic tool. Market. Intell. Plan. 2005, 23, 155-171. [CrossRef]

78. Hai, H.-L. Assessing The SMEs' Competitive Strategies on the Impact of Environmental Factors: A Quantitative SWOT Analysis Application. WSEAS Trans. Inf. Sci. Appl. 2008, 5, 1701-1710.

79. Vaishampayan, G.R. Study of different EMS with SWOT, energy and cost benefit analysis and star rating system for integrated EMS with gap analysis for sustainable development in construction sector. Spec. Issue Int. J. Electron. Commun. Soft Comput. Sci. Eng. 2012, 2, 10.

80. Lozano, M.; Vallés, J. An analysis of the implementation of an environmental management system in a local public administration. J. Environ. Manag. 2007, 82, 495-511. [CrossRef] [PubMed]

81. Jain, S.; Pant, P. Environmental management systems for educational institutions. Int. J. Sustain. High. Educ. 2010, 11, 236-249. [CrossRef]

82. Polankova, M.; Manlig, F.; Kralikova, R. Environmental reporting in the enterprise and related issues. MM Sci. J. 2015, 2015, 691-695. [CrossRef]

83. Zhang, W.; Wang, W.; Wang, S. Environmental performance evaluation of implementing EMS (ISO 14001) in the coating industry: Case study of a Shanghai coating firm. J. Clean. Prod. 2014, 64, 205-217. [CrossRef]

84. Ejdys, J. The Role of Internal Stakeholders in the Process of Creation Social Responsible Long-Term Care System in Poland. In Country Experiences in Economic Development, Management and Entrepreneurship; Springer: Cham, Switzerland, 2017; pp. 733-744.

85. Pauliuk, S. Critical appraisal of the circular economy standard BS 8001:2017 and a dashboard of quantitative system indicators for its implementation in organizations. Resour. Conserv. Recycl. 2018, 129, 81-92. [CrossRef]

86. Jackson, S.L. The ISO 14001 Implementation Guide Creating an Integrated Management System; Wiley: New York, NY, USA, 1997.

87. ISO. ISO 14001:2015-Environmental Management Systems-A Practical Guide for SMEs; International Organization for Standardization: Geneva, Switzerland, 2017.

88. Dentch, M.P. The ISO 14001:2015 Implementation Handbook: Using the Process Approach to Build an Environmental Management System; ASQ: Milwaukee, WI, USA, 2016.

89. Link, S.; Naveh, E. Standardization and Discretion: Does the Environmental Standard ISO 14001 Lead to Performance Benefits? IEEE Trans. Eng. Manag. 2006, 53, 508-519. [CrossRef]

90. Castka, P.; Prajogo, D. The effect of pressure from secondary stakeholders on the internalization of ISO 14001. J. Clean. Prod. 2013, 47, 245-252. [CrossRef] 
91. Qi, G.; Zeng, S.; Li, X.; Tam, C. Role of Internalization Process in Defining the Relationship between ISO 14001 Certification and Corporate Environmental Performance. Corp. Soc. Responsib. Environ. Manag. 2012, 19, 129-140. [CrossRef]

92. Ivanova, A.; Gray, J.; Sinha, K. Towards a unifying theory of management standard implementation. Int. J. Oper. Prod. Manag. 2014, 34, 1269-1306. [CrossRef]

93. Curkovic, S.; Sroufe, R. Using ISO 14001 to promote a sustainable supply chain strategy. Bus. Strateg. Environ. 2011, 20, 72-93. [CrossRef]

94. Paterson, F. The Auditor's Tale: Conformity Assessment as Seen by a Practitioner. ISO Manag. Syst. 2002, 4, 47-52.

95. Switzer, J.; Ehrenfeld, J. Independent Environmental Auditors: What Does ISO 14001 Registration Really Mean? Environ. Qual. Manag. 1999, 9, 17-33.

96. Council of the European Union. Proposal for a Regulation of the European Parliament and of the Council Setting Out the Requirements for Accreditation and Market Surveillance Relating to the Marketing of Products (2007/0029); Council of the European Union: Brussels, Belgium, 2008.

97. Morrison, J.; Cushing, K.; Day, Z.; Speir, J. Managing a Better Environment: Opportunities and Obstacles for ISO 14001 in Public Policy and Commerce; Pacific Institute: Oakland, CA, USA, 2000.

98. Thione, L. Improving World-Wide Credibility of Management System Certification; European Accreditation: Paris, France, 2006.

99. Ejdys, J.; Matuszak-Flejszman, A.; Szymanski, M.; Ustinovichius, L.; Shevchenko, G.; Lulewicz-Sas, A. Crucial factors for improving the ISO 14001 Environmental Management System. J. Bus. Econ. Manag. 2016, 17, 52-73. [CrossRef]

100. Schylander, E.; Martinuzzi, A. ISO 14001-Experiences, effects and future challenges: A national study in Austria. Bus. Strateg. Environ. 2007, 16, 133-147. [CrossRef]

101. Perez, O.; Amichai-Hamburger, Y.; Shterental, T. The dynamic of corporate self-regulation: Iso 14001, environmental commitment, and organizational citizenship behavior. Law Soc. Rev. 2009, 43, 593-630. [CrossRef]

102. Boiral, O. Corporate Greening Through ISO 14001: A Rational Myth? Organ. Sci. 2007, 18, 127-146. [CrossRef]

103. Poksinska, B.; Dahlgaard, J.J.; Eklund, J.A.E. Implementing ISO 14000 in Sweden: Motives, benefits and comparisons with ISO 9000. Int. J. Qual. Reliab. Manag. 2003, 20, 585-606. [CrossRef]

104. Tan, L.P. Implementing ISO 14001: Is it beneficial for firms in newly industrialized Malaysia? J. Clean. Prod. 2005, 13, 397-404. [CrossRef]

105. Laskurain, I.; Ibarloza, A.; Larrea, A.; Allur, E. Contribution to Energy Management of the Main Standards for Environmental Management Systems: The Case of ISO 14001 and EMAS. Energies 2017, 10, 1758. [CrossRef]

106. Gnoni, M.G.; Lanzilotto, A. The GreenSCOR: A critical assessment for supporting effective green supply chain management. In XVIII Summer School "Francesco Turco"-Industrial Mechanical Plants; AIDI: Rome, Italy, 2013; pp. 256-261.

107. Massarenti, U. Rischio di Impresa—Focus on Standards; TÜV Italia: Milan, Italy, 2012.

108. Yiridoe, E.K.; Clark, J.S.; Marett, G.E.; Gordon, R.; Duinker, P. ISO 14001 EMS standard registration decisions among Canadian organizations. Agribusiness 2003, 19, 439-457. [CrossRef]

109. Nazarko, J.; Ejdys, J.; Halicka, K.; Magruk, A.; Nazarko, Ł.; Skorek, A. Application of Enhanced SWOT Analysis in the Future-oriented Public Management of Technology. Procedia Eng. 2017, 182, 482-490. [CrossRef]

(C) 2018 by the authors. Licensee MDPI, Basel, Switzerland. This article is an open access article distributed under the terms and conditions of the Creative Commons Attribution (CC BY) license (http://creativecommons.org/licenses/by/4.0/). 